\title{
Modelling Farmers Investment in Agrochemicals: The Experience of Smallholder Cocoa Farmers in Ghana
}

\author{
Gideon Danso-Abbeam ${ }^{1, *}$, Edinam Dope Setsoafia ${ }^{1} \&$ Isaac Gershon Kodwo Ansah $^{1}$ \\ ${ }^{1}$ Dept. of Agriculture and Resource Economics, University for Development Studies, \\ Nyankpala Campus, Tamale, Ghana \\ *Corresponding author: Dept. of Agriculture and Resource Economics, University for \\ Development Studies, Nyankpala Campus, Tamale, Ghana. Tel: 233-249-253-902. E-mail: \\ nanayawdansoabbeam@gmail.com
}

Received: July 15, 2014 Accepted: September 15, 2014 Published: October 21, 2014

doi:10.5296/rae.v6i4.5977ＵRL: http://dx.doi.org/10.5296/rae.v6i4.5977

\begin{abstract}
The study analyzes the effects of the determinants of farmer's adoption of and investment in agrochemicals by collecting primary data from 156 sampled cocoa farmers in the Sefwi-Wiawso Municipality of Ghana. Descriptive statistical technique was employed to analyze demographic and farm-specific characteristics as well as the adoption rate and expenditure on agrochemicals. The findings highlighted the fact that, though a large proportion of farmers in the study area use agrochemicals, the intensity and amount spent to purchase these inputs are quite low. The Tobit regression model was used to identify and quantify the effects of the determinants of farmer's investment in agrochemicals. The results generally indicate that the sex of the farmer, age of the farmer, household size, educational attainment, mean age of cocoa farms, farm size and farmers previous output are all important variables in explaining farmers decision to invest in agrochemicals. The paper concludes by recommending that strategic policies orienting towards improving the adoption rate as well as targeting farmers who are less likely to invest in agrochemicals is a pressing issue.
\end{abstract}

Keywords: agrochemical input; demographic factors; farm-specific characteristics; Tobit Model; Cocoa Industry; Ghana 


\section{Introduction}

The importance of Agriculture to the development of developing economies in the World cannot be over-emphasized. In a period of rapid globalization and market liberalization, African countries are pursuing their comparative productive advantage to foster growth in a new liberal economic context. The quest for this comparative advantage implies a continuous if not a larger role for tropical commodity exports to generate foreign exchange and promote economic growth (World Bank, 2003). Most developing countries such as Ghana, Cote d'Ivoire, etc., depend largely on exports proceeds from primary products such as tree crops.

Among the perennial tree crops, cocoa sector is of particular interest for West and Central Africa, and for the global chocolate industry. Producing countries derive a large proportion of their foreign income from cocoa. Over the past ten years, West African countries have contributed the largest quantity of the world's cocoa, ranging between $54 \%$ and $71 \%$ of the total production (Awuah, 2002; FAO, 2004). For example, in 2001, Côte d'Ivoire exported more than 1.4 million tons of cocoa. This contributed about 40 percent of exports, 14 percent of GDP, and more than 20 percent of government income (Nkamleu\&Kielland, 2006). The cocoa sector in Ghana employs about 800,000 smallholder farm families providing food, employment, income, tax revenue and foreign exchange earnings for the government. The contribution of the sector has been very impressive over the last decade. For instance, in 2008 the sector contributed about $28.5 \%$ of Ghana's foreign exchange earnings out of about $38 \%$ by the agriculture sector (ISSER, 2008).

In Ghana, cocoa production has been fluctuating over the last decades ranging from 350,000 tons in 1998 to about 750,000 in 2004/2005 cocoa season. However, in the last decade, growth in the sector has been increasing at an increasing rate with a record-breaking of about $1,000,000$ tons in 2012 cocoa season. It is believed that this increase in output is attributed to a number of interventions including the cocoa Hi-Tech programme popularly known as "Mass Spraying Exercise". In spite of this tremendous increase in production, average yields per hectare is still below the potential estimated average of about $1000 \mathrm{~kg} / \mathrm{ha}$. Ghana's yield/ha is about $400 \mathrm{~kg}$ which is substantially lower than those observed in some of the cocoa producing countries such as Malaysia $(1800 \mathrm{~kg} / \mathrm{ha})$ and Cote d'Ivoire $(800 \mathrm{~kg} / \mathrm{ha})($ Binamet al., 2008; Barrietoset al., 2008 ).

The low productivity of cocoa is partially attributed to the depleting of soil nutrient, farmers inability to control pests and diseases as well as escalating cost of inputs in recent years. The cost of factor inputs results in farmers reducing the quantity of inputs use on their farms. The most important of these inputs are labour, fertilizer (to improve soil fertility), insecticides and fungicides (for controlling pests and diseases). The use of agrochemicals to provide nutrients for soil and pests and diseases control is an important issue under investigations in the Ghanaian cocoa industry. It has become a well-known fact that, one of the measures to increase cocoa productivity is through fertilization and control of pest and diseases. Appiahet al., (1997) reported a doubling of cocoa yields over a four-year period after the application of 4.94 bags of triple super phosphate and 2.49 bags of muriate of potash per hectare on on-farm trials in Ghana. 
The most damaging disease attacking cocoa is the fungal disease called "black pod". This disease is caused by two main species namely pytophthora megakarya and pytophthora palmivora which are of economic significance. The black pod disease is reported to be responsible for an estimated yearly loss of about $44 \%$ of the total global cocoa production (Nkamleuet al., 2007). The cocoa swollen shoot virus (CSSV)transmitted by sucking pests, mostly mealybugs is another dangerous disease causing roots and stem swelling in cocoa.

Insect pest, cocoa capsids or mirids (Distanthiella theobromae and Salbegella singularis) are widely perceived to be one of the serious constraints to cocoa production. Outbreaks of these pests and disease could cause up to about $75 \%$ loss of output especially in areas where trees have been neglected (Nkamleuet al., 2007). A parasitic plant called mistletoe is also another serious problem in cocoa production. It usually occurs in newly established cocoa farms after the primary forest has been cleared. Other insect pests are mealybugs (planococcus and stictococcus species) and nematode parasites (meliodogyne). These are most significant species because of the extent of damages they cause and their widespread occurrence in cocoa growing regions.

In an attempt to mitigate the challenges of low productivity level, the Ghana COCOBOD introduced a technology package which includes cocoa diseases and pests control programme (CODAPEC or mass spraying of cocoa farms) and Cocoa High Technology programmes, which provides free inputs and labour for the control of capsids and black pod as well fertilizer to cocoa farmers on credit. This is because the spraying frequency of the "mass spraying exercise" is not adequate and cocoa farmers are expected to do additional spraying. For effective and sustainable control of pest and diseases, one of the components of the technology is the requirement that cocoa farmers spray their farms with insecticides four times per cocoa year. Spraying is done from the month of August to December, leaving out November for harvesting and to ensure that treatment coincides with the main period of capsid or mirid population increase which usually occurs between August and November (ICCO, 2008; Adu-Acheamponget al., 2007). The recommended chemicals used in controlling capsid in Ghana include Confidor 200SL and Cocostar EC. The application is done by the use of motorized mix-blower machine. Moreover, spraying against black pod is done nine times per year starting from the month of March and continuing every two to three weeks whilst fertilizer is applied once every year with three bags of fertilizer per hectare. Dormonet al., (2007) reported that the use of chemical in controlling pests, though effective, comes with its own challenges regarding its applications and adoption.

To attain the goals of increasing productivity to one ton per hectare as achieved by other cocoa producing countries, cocoa farmers in Ghana need to be encouraged to increase productivity through the use of agrochemicals. To design such strategies, information is needed about farmers' current use of agrochemical inputs and the factors that shape the adoption of these and the intensity with which they are used. The main objective of the study is to model cocoa farmer's expenditure in agrochemical application, specifically to estimate the quantitative effects of the determinants of farmer's expenditure on agrochemicals. Information about farmer's current chemical inputs usage and the factors that affect adoption of these agrochemicals as well as the intensity of utilization is very critical in designing 
farm-level policies. A better understanding of these issues presents opportunities for policy planners to devise a strategy that aims at intensifying the use of the few land areas left for cropping and save our dear forest.

\section{Methodology}

\subsection{Study Area, Data and Sampling Technique}

Sefwi-Wiawso Municipality forms part of the 22 metropolitan, municipalities and districts in the Western region of Ghana. It has Wiawso as its administrative capital and shares boundaries with Bibiani-Anhwiaso-Bekwai to the east, with Bodi district to the West, to the North with Aowin district all in the Western region and to the south with Asunafo South in the Brong-Ahafo region. The topology of the Municipality is roughly rectangular with the area perimeter of about 2635 square kilometers and the Municipal capital lying almost on the extreme eastern perimeter. It falls within the tropical rainforest climatic zone with warm temperature throughout the year and moderate to heavy rainfall. It has a total estimated population of about 139,200 people with agriculture and its related work as the major economic activities. The soil type is of forest and supports the cultivation of crops such as cocoa, oil palm, maize, cassava, plantain and cocoyam with cocoa been the major perennial tree crop serving as a source of income for majority of farmers in the area.

The study used cross-sectional data from ten communities randomly selected from the Sefwi-Wiawso Municipality of Ghana. To aid the process of sampling cocoa farm households from the communities, a list of cocoa farmers were obtained from the local offices of Ghana COCOBOD. The number of households selected from each community was based on the number of cocoa farms in each community. A total of 156 households were randomly selected from the ten communities. A well-structured questionnaire was administered through interview schedule to capture data on demographic and farm-specific characteristics as well as the expenditure on agrochemical inputs of the farm households.

\subsection{Theoretical Framework}

It is assumed that the operational activities done by farmers in their cocoa farms are the application of agrochemicals to control pest and diseases and improve soil nutrient. It is further assumed that cocoa farmers in the study area are rational producers and seek to minimize their expenditure concerning cocoa production subject to their output level constraint as follows:

Minimize:

$$
C=\sum_{i=1}^{n} w_{i} x_{i}
$$

Subject to

$$
f\left(x_{i} \ldots \ldots \ldots \ldots x_{m}\right)=y^{0}
$$

Where $\mathrm{C}$ denotes the cost of cocoa production, $w_{i}$ denotes factor prices of the $i^{\text {th }}$ input and 
$x_{i}$ denotes quantities of $i^{\text {th }}$ inputs applied and $\mathrm{y}^{0}$ denotes the parametric cocoa output constraint.

In this study, the input factors used in the production of cocoa are; quantity of insecticides used in controlling capsids, quantity of fungicides used in controlling black pod, quantity of fertilizer used to improve soil fertility, labour used in agrochemical application and managerial skills denoted by $x_{m . .}$ Management $\left(x_{m}\right)$ is captured by multiplicative vector of demographic and socio-economic characteristics of the cocoa farmer. The demographic characteristics include: Age (AGE), Sex (SEX), Household Head (HHH) and Household size (HHS). The socio-economic characteristics are farm size (FSIZE), number of extension visits (EXT), farmer's educational level (FEDU), number of hired labour to help manage the cocoa farm (HLAB), distance from farm to the farmer's village of residence (DIS), farmer's membership of farmer based organizations or group (FBO) and farm output for the last cocoa season (OUTPUT).

The Lagrangian function (L) of inputs employed based on equations [1] and [2] is specified as follows;

$$
L=\sum w_{i} x_{i}+\lambda\left(y^{0}-f\left(x_{i} \ldots \ldots \ldots \ldots \ldots \ldots x_{m}\right)\right.
$$

The first order conditions (FOC) or the necessary condition for cost minimization is obtained by differentiating the Lagrangian with respect to the input factors:

$$
\begin{aligned}
& \frac{\partial L}{\partial x_{i}}=w_{i}+\lambda f_{i}=0, \\
& \frac{\partial L}{\partial \lambda}=y^{0}-f\left(x_{i} \ldots \ldots \ldots x_{m}\right)=0
\end{aligned}
$$

The second order condition or sufficient conditions (SOC) for cost minimization states that the second differentials should be greater than zero or the relevant bordered Hessian determinant should be positive definite.

The factor demand equations of the various input factors can be determined by applying the implicit function theorem. This theorem states that if the determinants of the first partials of the systems of equations are non-zero, then the equations can be solved.

The demand equations are determined as follows:

$$
\begin{aligned}
x_{i}^{*} & =f\left(w_{i} \ldots \ldots \ldots x_{m}, y^{0}\right) \\
\lambda^{*} & =f\left(w_{i} \ldots \ldots \ldots x_{m}, y^{0}\right)
\end{aligned}
$$

The application of such theoretical model is not new. A few recent examples include Silberberg and Suen (2001) and Nkamleuet al., (2007) and therefore the theoretical framework for modeling farmer's investment in agrochemicals is similar to the one outlined. 


\subsection{Statement of Hypotheses}

The present study hypothesized that the demographic and farm specific characteristics of the cocoa farmers in the study area influences farmer's decision to invest in agrochemicals.

The working hypotheses are as follows:

Age (AGE) is expected to have a negative relationship with agrochemical investment in cocoa farms. Farmers tend to increase their risk aversion as they grow old whilst young farmers are more likely to take risk associated with innovations.

Sex (SEX) is hypothesized to be positively related to investment of agrochemicals. The applications of chemicals especially pesticides involve the use of heavy equipment such as watering cans which women are less likely to do.

Household Head (HHH) is expected to exert positive effect on agrochemical investment in cocoa farms. Men headed households are more likely to invest in agrochemicals on their farms than women headed households.

Household Size (HHS) is expected to have a positive influence on agrochemical investment. Household size is measure of availability of family labour which is potential determinant of technology adoption. Bonabanaet al (2001) found household size to have positive correlation with adoption of integrated pest management (IPM) practices.

Farmers Education (FEDU) is found to correspond positively with agrochemical adoption (Nkamleu and Adesina 2000, Asfaw and Admasie 2004). It enhances farmer's ability to acquire, understand and respond to information regarding new technology. This study therefore hypothesized that farmer's years of education exert positive influence on agrochemical investment.

Hired Labour (HLAB) is expected to have negative relationship with agrochemical adoption in cocoa farms. This is because a greater number of labourers hired to work on farm increases the cost of production. Farmers may therefore tend to reduce their cost by reducing the amounts of money spend on purchasing the agrochemicals.

Farm Size (FSIZE) have positive a prior expectation in this study. Farm size is used to measure the wealth of the farmer. A farmer with large farm size is ready to bear risk by investing in a technology.

Age of Cocoa Tree (ACT) is expected to have negative relationship with farmer's decision to invest in agrochemicals. The cocoa productivity cycle is such that age plays a very significant role over time. At age 0-10, yields of cocoa increases rapidly, between 11-30 years, yield increases but at a diminishing rate and after 30 years yields decline. The study therefore expects less intensive management as cocoa farm ages.

Farmers contact with extension (EXT) agents is hypothesized to have positive influence on the adoption of agrochemicals. Farmer's encounter with extension agents raise their level of awareness of pest and diseases, their devastating effects as well as their preventive and control measures. 
Membership of Farmers group (e.g. FBO's) is expected to have positive correlation with farmer's adoption of agrochemical technology package. Farmers group provides them with the opportunity to learn from each other and share new knowledge. Farmers then become aware of what is happening in their industry.

Distance from Farm (DIS) is expected to have negative influence on the probability of adoption of chemicals by farmers. Cocoa farmers that have their farms far away from their place of residence normally face some constraints especially with transportation of chemicals to the farms. In Ghana, road networks in the rural areas are very poor and even become worst during raining season. The poor road networks coupled with the fact that cocoa farmers in Ghana manage several plots of land at different locations make transportation of agrochemicals very difficult and as well makes extension visitation of farms virtually impossible.

Output of the last cocoa season (FOUPUT) is expected to correspond positively with farmer's decision to invest in agrochemical package. Farmers with larger output last season are expected to increase their current level of agrochemical expenditures.

\subsection{Analytical Framework}

Descriptive and inferential statistical tools were used to analyze the survey data to establish the adoption levels as well as amount of money cocoa farmers in the study area spend on Agrochemical Technology Package (ATP). The adoption levels were measured as the proportion of the respondents who had used this package (fertilizer application, insecticides application and fungicides). Econometric techniques were then used to determine whether socio-economic and farm-specific characteristics do affect farmer's investment decisions in cocoa agrochemicals.

\subsubsection{Model Specification (The Tobit Model)}

Following the theoretical background of this study, Tobit model was used to capture cocoa farmer's expenditure decisions, which was censored at zero. There is the likelihood that some farmers may not use any of the agrochemicals (insecticides, fungicides and fertilizer) and for this group of farmers in this study, farmers expenditure on agrochemical was captured as zero. This was to avoid censoring bias that Ordinary Least Square estimates could present. Many studies (Nkamleuet al., 2007, Nkamleu \& Tsafack 2007; Nkamleu, 2004; Holloway et al., 2004; Oladade, 2005; Degu et al., 2000)have used this procedure to study farmer's decision to adopt technology packages. While some models such as Heckman's could also present unbiased results. The Tobit model conserved the degrees of freedom and hence the selected model. The Tobit model is also relevant in a study like this where independent variables have continuous effects on the dependent variables. In fact, the dependent variable is a simultaneous measure of the farmer's decision to invest and the amount spent on agrochemicals.

Hence, farmer's expenditure decision on agrochemical usage is empirically estimated as; 


$$
\begin{aligned}
& I_{D}=a_{0}+a_{1} A G E+a_{2} H H H+a_{3} H H S+a_{4} G E N+a_{5} F E D U+a_{6} H L A B+a_{7} F S I Z E+a_{8} A C T \\
& +a_{9} D F A R M+a_{10} E X T+a_{11} F G M+a_{12} F O U T P U T_{-1}+\varepsilon_{i}
\end{aligned}
$$

ID Farmers investment decision measured by farmer's expenditure on agrochemicals in Ghana cedis $(\mathrm{GH} \phi)$

$A G E \quad$ Age of the cocoa farmer measured in years.

HHH Farm household head (dummy, 1 if farmer is the household head and 0 if otherwise)

HHS Household size

GEN Gender or sex of the farmer (dummy, 1 for Male and 0 for Female)

FEDU Farmer's educational level measured in years of obtaining formal education

$H L A B$ Number of hired labour that work on the farm per cocoa season

FSIZE Farm size measured in acres

$A C T$ Mean age of cocoa farm

DFARM Distance from farmer's village of residence to the farm field measured in $\mathrm{km}$

EXT Farmers contact with extension services (dummy, 1 if Yes and 0 if No)

FGM Farmers membership with any farm group (dummy, 1 if Yes and 0 if No)

FOUPUT- $_{1}$ Last season's output level measured in bags

$\varepsilon_{i} \quad$ Error term

\section{Empirical Results and Discussions}

\subsection{Farmers Socio-demographic Characteristics}

Table 1 reveals the socio-demographic characteristics of cocoa farmers in the study area. The age distribution of cocoa farmers ranges between 20 and 77 years. The study area exhibited an economic active cocoa farmer population (20-60 years) represented by 88.46 percent. However, majority (40.38 percent) of cocoa farmers in the study area are within 41-50 age brackets with the mean age of 45 years. This is comparable to that of the national average. The implication is that the quality of labour in the cocoa farm business is good and would have positive effects on productivity as it is easy for young and active farmers to adopt new technologies.

The study contended that cocoa farming in Sefwi-Wiawso Municipality is male dominated as male headed households constitute 69.23 percent and female headed households constitute 30.77 percent.

The attainment of formal educational by farmers has documented to have a positive effect on farming activities. Education helps farmers to understand the ins and outs of factor and 


\section{Macrothink}

Research in Applied Economics

ISSN 1948-5433 2014, Vol. 6, No. 4

product markets thereby exposing them to improved farm cultural practices. The study reveals that 14.75 percent had no formal education, 18.59 percent had primary education, 32.69 percent had middle school or Junior high school, 31.42 percent had secondary school education and 2.56 percent had tertiary education. Thus, the study area is dominated by farmers with relatively high level of education.

In terms of household size, majority of the respondents (63.45 percent) have household size ranging between 1 and 5 with the mean household size of 6 per household. The data set also indicates that majority ( 82 percent) of coca farmers in the Sefwi-Waiwso Municipality have more than fifteen years of experience in the cocoa industry, 11 percent had between $10-15$ years of experience and 7 percent had less than 10 years of experience in cocoa farming with a mean of 18 years of experience.

Table 1. Demographic Characteristics of Cocoa Farmers in the Study Area

\begin{tabular}{|c|c|c|}
\hline Variable Name & Frequency & Percentage \\
\hline \multicolumn{3}{|l|}{ Sex } \\
\hline Male & 118 & 69.23 \\
\hline Female & 38 & 30.77 \\
\hline Total & 156 & 100 \\
\hline \multicolumn{3}{|l|}{ Age } \\
\hline $20-30$ & 15 & 9.62 \\
\hline $31-40$ & 30 & 19.23 \\
\hline $41-50$ & 63 & 40.38 \\
\hline $51-60$ & 30 & 19.23 \\
\hline$>60$ & 18 & 11.54 \\
\hline Total & 156 & 100 \\
\hline \multicolumn{3}{|l|}{ Household Size } \\
\hline$=1$ & 6 & 3.85 \\
\hline $2-5$ & 99 & 63.46 \\
\hline $6-10$ & 33 & 21.15 \\
\hline$<10$ & 18 & 11.54 \\
\hline Total & 156 & 100 \\
\hline \multicolumn{3}{|l|}{ Education } \\
\hline No formal education & 23 & 14.75 \\
\hline Primary & 29 & 18.59 \\
\hline J.H.S & 51 & 32.69 \\
\hline Secondary & 49 & 31.42 \\
\hline Tertiary & 4 & 2.56 \\
\hline Total & 156 & 100 \\
\hline \multicolumn{3}{|l|}{ Experience } \\
\hline$<10$ & 11 & 7.05 \\
\hline $10-15$ & 127 & 81.41 \\
\hline$>15$ & 18 & 11.54 \\
\hline Total & 156 & 100 \\
\hline
\end{tabular}




\subsection{Farm Specific Characteristics}

With regards to farm characteristics, the average farm size under cultivation in the study area was 7.98 acres (3.23 hectares) with the average cocoa farm age of about 15 years. The result is consistent with the recent study by Danso-Abbeamet al., (2012) who reported that cocoa farming in Ghana is dominated by small scale producers with farm sizes ranging between 1 5 hectares. It is also not far from the previous study conducted by Ghana COCOBOD in 2002 which indicated that cocoa farms in Ghana are relatively small ranging between $0.4-4$ hectares.

\subsection{Agrochemical Adoption and Expenditure}

Table 2 indicates the adoption pattern of agrochemicals (fertilizer, insecticides and fungicides) usage and expenditure. The data set reveals that 93.59 percent, 60.1 percent and 64 percent have adopted fertilizer, insecticides and fungicides respectively. With regards to fertilizer usage, the result is in sharp contrast to the recent work of Aneani (2012) in Ghana and Ogunlade (2009) in Nigeria who reported that majority of cocoa farmers in Ghana and Nigeria do not apply fertilizer on their farms. The high usage of fertilizers by cocoa farmers in the study area could partially be attributed to the extensive education on the merits of fertilizer through the media as well as the recent increase in the number of extension personnel in the cocoa growing areas by the Ghana COCOBOD. However, in terms of insecticides and fungicides application, the results confirm the result obtain by Danso-Abbeam (2014) in the Bibiani-Anhiawso-Bekwai district of Ghana.

Table 2. Agrochemical Adoption and Expenditure

\begin{tabular}{|c|c|c|c|}
\hline Agrochemical Usage & Frequency & Percentage & $\begin{array}{c}\text { Average } \\
\text { Expenditure/acre }(G H \phi)\end{array}$ \\
\hline Use of Fertilizer & 146 & 93.59 & 97.75 \\
\hline Non-user of Fertilizers & 10 & 6.41 & \\
\hline Total & 156 & 100 & \\
\hline Use of Insecticides & 95 & 60.9 & 38.27 \\
\hline Non-user of insecticides & 61 & 39.1 & \\
\hline Total & 156 & 100 & \\
\hline Use of fungicides & 100 & 64.1 & 5.36 \\
\hline Non-user of fungicides & 56 & 35.9 & \\
\hline Total & 156 & 100 & \\
\hline Average expenditure/acre & & & 141.78 \\
\hline
\end{tabular}

Source: Authors computation

Overall, over 90 percent of cocoa farmers in the study area use agrochemicals (fertilizer, insecticides and fungicides) on their cocoa farms. The main types of fertilizers used were Asasewura, Oye Ade Yie and Sidalco liquid fertilizers. The main types of insecticides used 
were Akatemaster and Confide 200s1 whilst Ridomil, Funguran and Nordox were the main fungicides used in the study area. Cocoa farmers in Sefwi-Wiawso Municipality indicated the average amount spent on agrochemical input factors.

As table 2 indicates, the average expenditure on fertilizer per farmer per acre was GH 497.75 . Whilst on the average, a farmer in the study area spends GHф38.59 on insecticides per acre, only GHф5.67 was spent on fungicides per acre. The results again reveals that a Ghanaian cocoa farmer in the study area spends about GHф141.78 (\$45) per cocoa season on agrochemicals. This is relatively high compared with farmers in Cote d'Iviore where the average expenditure for agrochemicals per farmer per acre per cocoa season is around CFA 8000 (\$14) (Nkamleuet al., 2007). However, it is quite low compared with farmers in the Cameroonian cocoa industry where farmers spend about $\$ 30 /$ ha on fungicides only (Kazianga, 2002).

\subsection{Determinants of Agrochemical Adoption and Expenditure}

Tobit regression model was used to determine the effects of the determinants of agrochemical usage in the Sefwi-Wiawso Municipality. Generally, eight variables out of twelve included in the model are significant in explaining the determinants of farmer's adoption and expenditure on agrochemicals. The statistically significant variables includes; Age, gender, household size, education, farm size, age of cocoa farm, farm distance and previous year output.

The negative and significant sign of Age of farmers indicate that young cocoa farmers in the study area have greater likelihood of investing more in agrochemicals. The value of the marginal effect indicates that a one more year increase in the age of a cocoa farmer decreases the probability of investing in agrochemicals by 0.0166 units. This could partially be attributed to the fact that young people are more enthusiastic in taking risk associated with innovations. This is in line with a recent study by Gockowski \& Ndoumbe (2004) who reported that young farmers are more likely to adopt new technologies.

Previous studies in Africa by Malton (1994); Nkamleu \& Adesina (2000) reported that men are generally more likely to adopt new agricultural technologies than women. Their results are not different from the results of this study as gender is positively sign and has significant effects in explaining farmer's investment in agrochemicals. The marginal effect value implies that a more dominance of men over women in cocoa production in the study area will increase the probability of agrochemical usage by 0.2163 units. This is also in conformity to the recent study by Aneani et al., (2012) who reported that the gender of a Ghanaian cocoa farmer is an important variable in explaining his or her adoption decision concerning cocoa technology package.

The coefficient of household size is negatively signed and significant at 1 percent level of significance, indicating that larger household sizes are less likely to invest in agrochemicals. This is counterintuitive and stands contrary to our a priori expectation. However, this observation could partially be ascribed to the fact that large-sized families may have other expenditure items that compete with investment in agrochemicals for same family resources. The marginal effect of additional increase in household size will reduce the amount of money 
used to purchase inputs for cocoa production by 0.0488 units. The result is in agreement with the one documented by Nkamleu et al., (2007) who reported a negative relationship between family size and farmer's expenditure in agrochemicals.

Education has been documented to enhance farmer's abilities to acquire new information and respond quickly to changes in their environment, hence, educated farmers are more likely to adopt new agricultural technologies than their non-educated counterparts. The results from the study are not anything different as the education variable has a significant positive effect on farmer's investment in agrochemicals. The marginal effect of a unit increase (1 year) in farmer's level of education increases farmer's expenditure by 0.0193 . This also confirms the previous studies by Nkamleu \& Adesina (2000) and Asfaw \& Admassie (2004).

Table 3. Tobit Regression Estimates of Cocoa Farmers Expenditure in Agrochemicals

\begin{tabular}{lccl}
\hline Variable & Marginal Effects & Standard Error & $P$ - values \\
\hline Constant & 2.842578 & 0.1878003 & $0.000^{* * *}$ \\
Age & -0.0165865 & 0.0032866 & $0.000^{* * *}$ \\
Gender & 0.2162845 & 0.1242709 & $0.082^{*}$ \\
Household size & -0.0487555 & 0.0151736 & $0.001^{* * *}$ \\
Household head & 0.1483398 & 0.1167523 & 0.204 \\
Education & 0.0193169 & 0.0074297 & $0.009^{* * *}$ \\
Extension & 0.0092406 & 0.0870751 & 0.915 \\
FBO & 0.0363658 & 0.1055161 & 0.730 \\
Mean Age of Cocoa Farm & -0.0103293 & 0.0059964 & $0.085^{*}$ \\
Farm size & 0.028128 & 0.0107256 & $0.009^{* * *}$ \\
Output & 1.196349 & 0.1399483 & $0.000^{* * *}$ \\
Hired labour & 0.0137852 & 0.0106994 & 0.198 \\
Farm distance & 0.0722741 & 0.0293594 & $0.014^{* *}$ \\
\hline Log likelihood ratio test & -73.806824 & & \\
Pseudo ${ }^{2}$ & 0.1184 & & \\
Sample size & 156 & & \\
** \& * represents 1\%, 5\% and 10\% level of significance. &
\end{tabular}

The potential of cocoa farm productivity is also a function of tree characteristics such as age. The coefficient of the mean age of cocoa farm is negatively related to farmer's investment in agrochemicals and significant at 10 percent level of significance. Thus, the older the cocoa farms, the less likely farmers will apply agrochemicals. This is quite not different from the results obtained by Nkamleuet al., (2007) who reported that Ivorian farmers are less likely to use agrochemicals on their older cocoa farms.

The coefficient of farm size is positively signed and statistically significant at 1 percent level of significance. That is, farmers with larger farm sizes are more likely to increase their investment in agrochemicals. This supports the previous studies by Polson \& Spencer (1991) and recent study by Nkamleuet al., (2007) who documented positive correlation between total area cultivated and adoption of agrochemicals. 
Output from the last cocoa season can influence the expenditure on factor inputs in current season, including agrochemicals. The estimated Tobit model reveals a positive relationship between output of cocoa farmers and their investment in agrochemicals.

The farm distance though significant fails to meet our a priori expectation as it is positively signed, suggesting that the further away the farms are from the farmer's place of residence residence the greater the probability of investing in agrochemicals. This is contrary to what the study hypothesizes.

\section{Conclusions and Recommendations}

The study has focused on agrochemical usage by cocoa farmers in the Sefwi-Wiawso Municipality of Ghana by identifying the level of usage and the factors determining farmer's expenditure in agrochemicals. The study collected primary data from 156 sampled cocoa farmers in the Sefwi-Wiawso Municipality of Ghana. Descriptive statistical techniques were employed to analyze demographic and farm-specific characteristics as well as the adoption rate and expenditure on agrochemicals. The findings highlighted the fact that, though a large proportion of farmers in the study area use agrochemicals, the amount of money spent to purchase these inputs are quite low. These findings suggest the urgent need to formulate policies targeted at improving the intensity of agrochemical usage in the Ghanaian cocoa industry.

Further, factors influencing farmer's investment in agrochemicals were analyzed using the Tobit regression model. The major findings from the econometric results revealed that male farmers or farmers with high level of education, or have larger farm sizes and farmers with larger output sizes are more likely to invest in agrochemical inputs. Investments in agrochemical inputs are less likely for older farmers, farmers with large household sizes and farmers with aging cocoa farms. The results suggest that for Ghana to compete with her counterparts in the South-eastern Asian countries towards the one ton/ha productivity target, the use of agrochemicals must be increased through strategic policy oriented towards farmers who are less likely to invest in agrochemical inputs.

\section{References}

Adu-Acheampong R., Padi B., Ackonor J.B., Adu-Ampomah Y., \& Opoku I.Y. (2007). Field performance of Some Local and International Clones of Cocoa against Infestation by Mirids, pp. 187-188. In Eskes, A. B., \& Efron, Y. (eds.), Global Approaches to Cocoa Germplasm Utilization and Conservation.A Final Report of the CFC/ICCO/IPGRI Project on Cocoa Germplasm Utilization and Conservation: A global approach, 1998-2004.

Aneani, F., Anchirinah, V.M., Owusu-Ansah F., \& Asamoah, M. (2012). Adoption of some cocoa production technologies by cocoa farmers in Ghana. Sustainable Agriculture research, 1(1), 103-117. http://dx.doi.org/10.5539/sar.v1n1p103 
Appiah, M.R., Ofori-Frimpong K., Afrifa, A. A., \& Asante, E. G. (1997). Prospects of fertilizer use in the cocoa industry in Ghana. Proceedings of the Soil Science Society of Ghana, 15, 215-21.

Asfaw, A., \& Admassie, A. (2004). The role of education on the adoption of chemical fertilizer under different socioeconomic environments in Ethiopia. Agricultural Economics, 30(3), 215-28. http://dx.doi.org/10.1016/j.agecon.2002.12.002

Awua, P. K. (2002). Cocoa Processing and Chocolate Manufacture in Ghana: The success story that demolished a myth. Saffron Walden, UK.

Barrietos, S. W., Asenso-Okyere, K., Asuming-Brempong, S., Sarpong, D., Anyidoho, N. A., Kaplinsky, R., \& Leavy, J. (2008). Mapping Sustainable Production in Ghanaian Cocoa. A report to Cadbury by the Institute of Development Studies and the University of Ghana.

Binam, J. N., Gockowski, J., \& Nkamleu, G. B. (2008). Technical Efficiency and Productivity Potential of Cocoa Farmers in West African Countries. The Developing Economics, XLVI(3), 242-63

Bonabana, J. D., Taylor, B., Kasenge, V., Bashaasha, B., \& Erbaugh, M. J. (2001). Assessing the Economic Impacts of IPM CRSP Strategies on Groundnut Diseases in Kumi-Uganda. Annual Report, IPM CRSP.

COCOBOD (2002). Socio-Economic Study. Final Report, Cocoa Board, Ghana.

Danso-Abbeam, G. (2014). Resource-Use-Efficiency in Cocoa Industry: The Experience of Smallholder Cocoa Farmers in Ghana. LAP LAMBERT Academic Publishing, Germany.

Danso-Abbeam G., Aidoo R., Agyemang K. O., \& Ohene-Yankyera, K. (2012). Technical Efficiency in Ghana's Cocoa Industry: Evidence from Bibiani-Anhwiaso-Bekwai District. Journal of Development and Agricultural Economics, 4(10), 287-294. http://dx.doi.org/10.5897/JDAE12.052

Degu, G., Mwangi, W., Verkuij, H., \& Abdishekur, W. (2000). An assessment of the adoption of seed and fertilizer packages and the role of credit in smallholder maize production in Sidama and North Omo Zone, Ethiopia. Mexico, D.F.: International Maize and Wheat Improvement Center (CIMMYT) and Ethiopian Agricultural Research Organization (EARO).

Dormon, E. N. A., Van Huis, A., \& Leeuwis, C. (2007). Effectiveness and profitability of pest management for improving yield on smallholder cocoa farms in Ghana. International Journal of Tropical Insect Science, 27(1), 27-39. http://dx.doi.org/10.1017/S1742758407727418

Gockowski, J., \& Ndoumbé, M. (2004). The adoption of intensive monocrop horticulture in southern Cameroon. Agricultural Economics, 30(3), 195-202. http://dx.doi.org/10.1016/j.agecon.2002.11.002 
Holloway, G., Nicholson, C., Delgado, C., Staal, S., \& Ehui, S. (2004). A revisited Tobit procedure for mitigating bias in the presence of non-zero censoring with an application to milk-market participation in the Ethiopian highlands. Agricultural Economics, 31(1), 97-106. http://dx.doi.org/10.1111/j.1574-0862.2004.tb00224.x

Institute of Statistical, Economic and Social Research (ISSER) (2008). The State of the Ghanaian Economy in 2008. University of Ghana, Legon.

International Cocoa Organisation (ICCO). Retrieved fromhttp://www.icco.org/aboutpest.aspx

Kazianga, H, (2002). Adoption of improved cocoa technologies in Cameroon. PhD Thesis, Department of Agricultural Economics, Perdue University, West Lafayette, USA.

Matlon, P. J. (1994). Indigenous land use systems and investments in soil fertility in Burkina Faso. In Bruce, J. W., \& Migot-Adholla, S. E. (Eds.), Searching for Land Tenure Security in Africa (pp. 41-69). Dubuque, Iowa: Kendall/Hunt.

Nkamleu, G. B., Keho, Y., Gockowask, J., \& David, S. (2007). Investing in Agrochemicals in the cocoa sector of Cote d'Ivoire: Hypotheses, Evidence and Policy Implications. African. Journal of Agricultural and Resource Economics, 1(2), 145-166.

Nkamleu, G.B., \& Adesina, A.A. (2000). Determinants of chemical input use in peri-urban lowland systems: Bivariate probit analysis in Cameroon. Agricultural Systems, 63(2), 111-121. http://dx.doi.org/10.1016/S0308-521X(99)00074-8

Nkamleu, G.B., \& Kielland, A. (2006). Modeling farmers' decisions on child labor and schooling in the cocoa sector: A multinomial logit analysis in Côte d'Ivoire. Agricultural Economics, 35(3), 319-333. http://dx.doi.org/10.1111/j.1574-0862.2006.00165.x

Nkamleu, G. B., \& Tsafack, R. (2007). On measuring indebtedness of African countries. African Finance Journal, 9(1), 21-38.

Nkamleu, G. B. (2004). Productivity growth, technical progress and efficiency change in African agriculture. Africa Development Review, 16(1), 203-22.

Ogunlade, M. A., Oluyole, K. A., \& Aikpokpodion, P. O. (2009). An Evaluation of the level of fertilizer utilization for cocoa production in Nigeria. Cocoa Research Institute of Nigeria, P.M.B. 5244, Idi-Ayunre, Ibadan, Nigeria

Oladede, O. I. (2005). A Tobit analysis of propensity to discontinue adoption of agricultural technology among farmers in South-Western Nigeria. Journal of Central European Agriculture, 6(3), 249- 254.

Silberberg, E., \& Suen, W. (2001). The Structure of Economics: A Mathematical Analysis. Irwin McGraw-Hill, New York, U.S.A.

World Bank. (2003). A Multi-Country Agricultural Productivity Program for Africa. Washington: World Bank. 


\section{Copyright Disclaimer}

Copyright reserved by the author(s).

This article is an open-access article distributed under the terms and conditions of the CreativeCommons Attribution license (http://creativecommons.org/licenses/by/3.0/). 